\title{
EDITORIAL
}

\section{IN THE OCTOBER 2004 ISSUE OF CLÍNICAS}

\author{
Mauricio Rocha-e-Silva, Editor
}

With this October issue, CLÍNICAS begins to introduce a new style. At this point we have started to reorganize our Editorial Board to cover a worldwide spectrum of expertise. Next, will be internet online submission and handling of manuscripts which we hope to have operational by early 2005 . We are looking forward to receiving your original paper, or your case report. In this issue we are publishing eleven original research papers, two case reports and two reviews:

GUIDO MC et al. ${ }^{1}$ point out that left ventricular hypertrophy following volume overload is regarded as an example of cardiac remodeling without increased fibrosis accumulation. Infarction is associated with increased fibrosis within the noninfarcted, hypertrophied myocardium, particularly in the subendocardial regions. They suggest that, as also occurs postinfarction, low coronary driving pressure may also interfere with accumulation of myocardial fibrosis following aortocaval fistula. The purpose of the investigation was to study the role of acute hemodynamic changes in subsequent deposition of cardiac fibrosis in response to aortocaval fistula. Authors conclude that the coronary driving pressure falls and ventricular pressures increase early after aortocaval fistula and that these effects are associated with subsequent myocardial fibrosis deposition.

BRICKS LF et al. ${ }^{2}$ note that
Haemophilus influenzae is one of the most important bacterial agents of otitis and sinusitis, and that $\mathrm{H}$. influenzae type $b(\mathrm{Hib})$ is one of the main causes of meningitis, pneumonia, and septicemia in non-vaccinated children under 6 years of age. The aims of the study were to determine the prevalence of $\mathrm{H}$. influenzae and Hib oropharyngeal colonization prior to the onset of the Hib vaccination program in Brazil in previously healthy children and to assess the susceptibility profile of this microorganism to a selected group of antimicrobials that are used to treat acute respiratory infections. Authors show a low prevalence of colonization by penicillin-resistant strains which indicates that it is not necessary to substitute ampicilin or amoxicilin to effectively treat otitis and sinusitis caused by $\mathrm{H}$. influenzae in the area where the study was conducted.

DARCIE $S$ et al. ${ }^{3}$ have evaluated the evolution of glycemic levels in newborns of hypertensive mothers according to maternal treatment (isradipine, atenolol, or low sodium diet). Their results suggest a similar effect of the 3 types of treatment upon newborn glycemia. Correlation analysis suggests that isradipine could have

From Hospital das Clínicas, Faculty of Medicine, University of São Paulo - São Paulo/SP, Brazil.

E-mail: mrsilva@incor.usp.br effects upon newborn glycemia only after birth, whereas atenolol could act earlier. The results also point to the need for glycemic control from the first hour postpartum of newborns of hypertensive mothers whether they have, or have not, undergone treatment with antihypertensive drugs.

AOKI $\mathrm{V}$ et al. ${ }^{4}$ take up the theme of pemphigus foliaceus (fogo selvagem), an autoimmune intraepidermal blistering disease in which immunoglobulin $\mathrm{G}$ ( $\mathrm{IgG}$ ) autoantibodies are directed against desmosomal glycoproteins. The aim of the study was to determine the $\operatorname{IgG}$ subclass profiles of endemic pemphigus foliaceus (fogo selvagem) and pemphigus vulgaris utilizing indirect immunofluorescence. The conclusion is that subclass characterization of immunoglobulin $\mathrm{G}$ autoantibodies is a useful tool for pemphigus follow-up, since immunoglobulin G4 (IgG4) is the subclass related to recognition of pathogenic epitopes, consequently with disease activity. Careful monitoring should be performed for fogo selvagem in clinical remission with a homogeneous $\mathrm{IgG} 4$ response, since this may indicate frequent relapses.

BARROS ACSD et al. ${ }^{5}$ have tested an experimental model of chemical mammary carcinogenesis induction in rats. By administering 7,12-dimethylbenz(a)anthracene (DMBA) intragastrically they show that the experimen- 
tal animal model of chemical mammary induced carcinogenesis is feasible, and can be used for further experiments on the role of tumorigenic biomodulation.

SOUTO CAV et al. ${ }^{6}$ evaluate the hypothesis that a 7-day period of indwelling catheter after radical retropubic prostatectomy is effective and safe without the need of performing cystography. The study included 73 patients. Data show that withdrawal of the urethral catheter 7 days after radical retropubic prostatectomy, without performing cystography, has a low rate of short-term complications that are equivalent to withdrawal 14 days after the surgery.

SUGAYAMA SMM et al. ${ }^{7}$ studied the 20 patients with the WilliamsBeuren syndrome, a rare multiple anomalies/mental retardation syndrome caused by deletion of contiguous genes at chromosome region $7 q 11.23$, to determine the frequency and the types of renal and urinary tract anomalies. Twenty patients with the syndrome were included. Deletion of the elastin gene was shown in 17 out of 20 patients; renal alterations dysfunctional voiding, and arterial hyper- tension were diagnosed. In correlation with the deletion it is concluded that performing a systematic laboratory and sonographic evaluation of the patients is recommended.

SOEIRO EMD et al. ${ }^{8}$ studied 92 children and adolescents with idiopathic nephrotic syndrome, a condition which presents alterations in their cellular and humoral immune reactions that predispose to the development of infectious processes. The infectious processes in these patients with idiopathic nephrotic syndrome were characterized. It is shown that the nephrotic condition, whether as part of a course of frequent relapses, steroid dependence, or steroid resistance, conferred greater susceptibility to infection among the patients with idiopathic nephrotic syndrome. Best preventive action against infection in this disease is to control the nephrotic state.

PEREZ et al. ${ }^{9}$ studied the occurrence of microsatellite instability in 24 patients presenting with gastric carcinoma and treated by radical surgery. Five patients $(21 \%)$ had tumors that were MSI+ in at least 1 marker, three of them in the group with Lauren's in- testinal-type gastric carcinoma, and two in the group of diffuse-type gastric cancer. Microsatellite instability has been reported in association with older age of presentation, distal tumor location, early disease staging, and better overall prognosis

FERREIRA MC et al. ${ }^{10}$ reexamine a recently developed method for evaluation of cutaneous sensibility in the feet of diabetic patients, using a PressureSpecified Sensory Device. Diabetic patients had poorer sensibility compared to controls and diabetic patients with ulcers exhibited a poorer sensibility compared to diabetic patients without ulcers. Due to the small number of patients compared, the results should be taken as a preliminary report.

PRACCHIA LF et al. ${ }^{11}$ compared frequency and probability of catheterrelated infection for two types of longterm intravenous devices in 96 adult hematology-oncology patients: partially $(\mathrm{n}=55)$ or completely implanted devices $(n=42)$. Infection risk was found to be significantly lower in completely implanted devices as compared to partially implanted ones.

In addition, we publish two case reports $^{12,13}$ and two reviews ${ }^{14,15}$.

\section{REFERENCES}

1. Guido MC, Frimm CC, Koike MK. Low coronary perfusion pressure is associated with endocardial fibrosis in a rat model of volume overload cardiac hypertrophy. Rev. Hosp. Clín. Fac. Med. S. Paulo 59(5): 2004

2. Bricks LF, Mendes CMF Lucarevschi BR Paz CO et al. Oropharyngeal colonization by haemophilus influenzae in healthy children from taubaté (São Paulo), prior to the haemophilus influenzae type B vaccination program in Brazil. Rev. Hosp. Clin. Fac. Med. S. Paulo 59(5): 2004

3. Darcie S, Leone CR, Calil VMLT, Prescinotti EP et al. Glycemia in newborns of hypertensive mothers according to maternal treatment. Rev. Hosp. Clín. Fac. Med. S. Paulo 59(5): 2004

4. Aoki V, Huang MHT, Périgo AM, Fukumori lmi ET al. Endemic pemphigus foliaceus (fogo selvagem) and pemphigus vulgaris: immunoglobulin $\mathrm{G}$ heterogeneity detected by indirect immunofluorescence. Rev. Hosp. Clín. Fac. Med. S. Paulo 59(5): 2004
5. Barros ACSD Naomi E, Muranaka K, Mori LJ et al. Induction of experimental mammary carcinogenesis in rats with 7,12dimethylbenz(a)anthracene. Rev. Hosp. Clín. Fac. Med. S. Paulo 59(5): 2004.

6. Souto CAV, Rhoden E, De Conti R, Chammas Jr, M et al. Urethral catheter removal 7 or 14 days after radical retropubic prostatectomy: clinical implications and complications in a randomized study. Rev. Hosp. Clin. Fac. Med. S.Paulo 59(5): 2004

7. Sugayama SMM, Koch VHK, Furusawa EA, Leone C et al. Renal and urinary findings in 20 patients with Williams-Beuren syndrome diagnosed by fluorescence in situ hybridization (fish). Rev. Hosp. Clin. Fac. Med. S. Paulo 59(5):2004

8. Soeiro EMD, Koch VH, Fujimura MD, Okay Y. Influence of nephrotic state on the infectious profile in childhood idiopathic nephrotic syndrome. Rev. Hosp. Clín. Fac. Med. S. Paulo 59(5): 2004. 
9. Perez RO, Jacob CE, D'Ottaviano FL, Alvarenga $\mathrm{C}$ et al. Microsatellite instability in solitary and sporadic gastric cancer. Rev. Hosp. Clín. Fac. Med. S. Paulo 59(5): 2004

10. Ferreira MC Rodrigues L, Fels K. New method for evaluation of cutaneous sensibility in diabetic feet. preliminary report. Rev. Hosp. Clín. Fac. Med. S. Paulo 59(5): 2004.

11. Pracchia LF, Dias LCS, Dorlhiac-Llacer PE, Chamone DAF. Comparison of catheter-related infection risk in two different long-term venous devices in adult hematology-oncology patients. Rev. Hosp. Clín. Fac. Med. S. Paulo 59(5): 2004.

12. Campos FG, Leite AF, Araujo SEA, Atuí FC et al. Anorectal leiomyomas: report of two cases with different anatomical patterns and literature review. Rev. Hosp. Clín. Fac. Med. S. Paulo 59(5): 2004
13. Souza SCM, Borges CTL, Jorgetti V, Pereira RMR. The effect of intravenous zoledronic acid on glucocorticoid-induced multiple vertebral fractures in juvenile systemic lupus erythematosus. Rev. Hosp. Clin. Fac. Med. S. Paulo 59(5):2004.

14. Menezes FS, Leite HP, Fernandes J. Benzecry SG et al. Hypophosphatemia in critically ill children. Rev. Hosp. Clin. Fac. Med. S. Paulo 59(5):2004.

15. Pasqualotto FF, Lucon, AM Sobreiro, BP Pasqualotto EB et al. The best infertility treatment for vasectomized men: assisted reproduction or vasectomy reversal Rev. Hosp. Clín. Fac. Med. S. Paulo 59(5): 2004 